\title{
Burdur-Gölhisar havzasında serpantin kayası üzerinde gelişen toprakların bitki besleme kapasiteleri
}

\section{Plant nutrient capacity of soils development on the serpentine rock in the Burdur- Gölhisar basin}

\author{
Sevda ALTUNBAŞ (iD \\ Akdeniz Üniversitesi, Ziraat Fakültesi, Toprak Bilimi ve Bitki Besleme Bölümü, 07070, Antalya, Türkiye \\ Sorumlu yazar (Corresponding author): S. Altunbaş, e-posta (e-mail): saltunbas@akdeniz.edu.tr
}

MAKALE BILGISII

Alınıș tarihi 12 Mart 2019

Düzeltilme tarihi 19 Nisan 2019

Kabul tarihi 26 Nisan 2019

\section{Anahtar Kelimeler:}

Bitki besleme

Toprak

Peridotit

Serpantin

\begin{abstract}
ÖZ
Demir, magnezyum ve silikat bileşiminde, ultramafik bir kaya olan peridodit- serpantin, okyanusların tabanına, okyanus ortası sırtlarından püsküren lavların yayılmasıyla oluşmuştur. Daha sonra bu kayalar orojenez ile yüzeye çıkmış ve toprak oluşum işlemleri başlamıştır. Peridotit serpantin kayaları silikat bileșiminde olduklarından en zor ayrıșan kayalardan bir tanesidir. Ayrışmanın ilk aşamalarında ortama bol miktarda kireç ve kil bırakırlar. Bu aşamada renkleri genellikle beyazımsı ve $\mathrm{pH}$ içerikleri de 9'a kadar ulaşabilmektedir. Katyon Değișim Kapasitesi (KDK) değerleri çok düşük, sığ topraklardır. Bu nedenle bitki besleme özellikleri zayıftır. Daha çok orman örtüsü altında yer alırlar veya ülkemizin çölleşme sahalarından bazılarını oluştururlar. İyi ayrıșmıș serpantin kayalarının rengi, kahverengi veya kırmızıdır. Toprak tekstürü, strüktürü ve $\mathrm{pH}$ aralıkları ise bitki yetiştiriciliğine uygundur. Alınan toprak örneklerinde fiziksel ve kimyasal analizler, Akdeniz Üniversitesi Ziraat Fakültesi Toprak Bilimi ve Bitki Besleme Bölümü Laboratuvarında yapılmıştır. Analiz sonuçlarına göre, iyi ayrışmış serpantin kayalarının yeterli bitki besin maddelerini içerdiği, düşük ve/veya yetersiz ayrışmış serpantinlerin ise bitki besleme kapasitelerinin düşük olduğu bulunmuştur.
\end{abstract}

\section{ARTICLE INFO}

Received 12 March 2019

Received in revised form 19 April 2019

Accepted 26 April 2019

\section{Keywords:}

Plant nutrient

Soil

Peridodite

Serpantine

\begin{abstract}
Peridotite-serpentine which is composed of ferro-magnesium silicate formed the lavas erupted from the mid-oceanic ridge spread on the ocean floor. After that the serpentine-peridotite mass was obducted by the tectonic movement occurred along the subduction zone that are seen along the orogenic belt. Peridotite-serpentine mass is one of the very low weathered rocks due to its silicate composition. During the it's weathering process abundant clay releases with white colour and its $\mathrm{pH}$ reach as high as 9. Cation exchangeable capacity (CEC) of the low weathered serpentine is very low and the depth of solum horizon is thin. Therefore plant nutrition features are weak. More are located under forest cover or some form of the field of desertification of our country. The colour of well decomposed serpentine in the rock is brown or red. Soil texture, structure and $\mathrm{pH}$ ranges are suitable for the cultivation of plant. Chemical and physical analyses of the serpentine soil samples were determined at the Soil Laboratory of Soil Science and Plant Nutriment Department of Akdeniz University. According to analysis, good weathered serpentine parent material contains enough plant nutriments; while low and/or unweathered serpentine has low plant nutrient due to plant nutrient are not released.
\end{abstract}

\section{Giriş}

Ülkemiz volkanik, tortul ve metamorfik kayaçların pek çok çeşidinin yer aldığ 1 zengin bir jeopark niteliğindedir. Söz konusu kayaçların ayrışma ürünü olan toprakların iyi anlaşılabilmesi, sinıflandırılıp, sınırlarının çizilmesi, haritalanması ve yetenekleri doğrultusunda kullanılabilmeleri için ise onları oluşturan ana kayalarının çok iyi bilinmesi gerekmektedir. Zira topraklar ana materyal, topoğrafya, zaman, canlılar ve iklim faktörlerinin etkisi ile oluşup karakter kazanan, canlı varlıklardır. Toprak oluşturan kayaçlar içerisinde, sınırlı alanlarda yer alan, ancak gerek oluşumları ve gerekse özellikleri bakımından araştırma konusu olan serpantinler özel bir yer tutmaktadır.

Kıta kütlesinin üst mantodan oluşan zıt yönlü akıntılarla parçalanarak binlerce km birbirinden uzaklaşmasıyla okyanuslar oluşmuştur. Bu oluşum sırasında yarıklardan çıkarak okyanus tabanına bazalt ve gabro ile demir magnezyum silikat bileșiminde olan peridotitler yayılmıștır. Peridotitlerin okyanus suyunu bünyesine alarak şişmesi ve hacim genişlemesi sonucu 
çatlaklar boyunca birbiri üzerinde kayarak parlak bir görünüm alan şekline serpantin denir (Şekil 1). Ayrıca, okyanusların yine üst mantoda oluşan akıntılarla kita kütlelerinin birbirine yaklaşarak kapanması sırasında okyanuslarda biriken tortulların kıvrılarak yükselmesiyle dağlar meydana gelmiştir. Dağ oluşumu sırasında okyanus tabanındaki peridotitler de sıkışma sonucu dilimlenerek yer yer dağ kuşaklarında yüzeye kadar çıkmıştır (Atalay 2016, 2017).

Deniz tabanına yayılan ultramafik bir kaya olan peridotitin bünyesine su almasıyla oluşan parlak yeşil görünümdeki serpantinler, demir magnezyum silikat bileşimindedir (Atalay 2016 2017). Yüksek miktarda magnezyum, demir ve olivin, piroksen gibi mafik mineraller içeren kayaç ve silikat mineralleri ultramafik kayaç (gabro, bazalt, peridotit gibi); $<\% 45$ silis $\left(\mathrm{SiO}_{2}\right)$ içeren kayaçlar ise ultrabazik kayaçlar olarak isimlendirilirler (Kruckeberg 2002). Pürüzsüz ve zeytin-yeşili renkte, alacalı, pullu olması nedeniyle latincede yılan anlamına gelen "serpentinus"dan adını almıştır. Serpantinit gibi serpantin içeren kayalar da geçmişten günümüze, kolay işlenebilir olmaları nedeniyle, birçok kültür tarafindan alet ve mücevher yapımında, törensel oymalarda, dekorasyonda, toplumların kültürlerini yansıtan tılsımların yapımında, yılan ısırıklarından korunmada kullanılmışlardır. Ayrıca, asbestler (chrysotile gibi), $\mathrm{Ni}, \mathrm{Cr}$ genellikle serpantin içeren kayalardan ekstrakte edilmektedir (Rajakaruna ve Boyd 2014).

Ultramafik kayaçlar yurdumuzun da birçok yerinde yamalı bir dağıllış göstermektedir (Şekil 2). Kütahya ve Balıkesir çevrelerinde, Antalya ve Muğla civarında, Hatay ve Adana civarında Amanos Dağları'nda, Doğu Toroslarda Mersin'in kuzeyi ve kuzeydoğusunda, Niğde ve Adana arasında Aladağ masifi içinde, Adana'dan-Erzincan'a kadar yüzlerce kilometrelik hat boyunca uzanır. Ayrıca Ankara ve Çanakkale çevrelerinde de lokal olarak rastlanmaktadır. Serpantinitlerin yayıldığı alanlar Türkiye'de endemizm bakımından önem taşımaktadır. Ayrıca serpantinitler maden cevheri bakımından da zengindirler (Hoşgören 2000).

Peridotit-serpantin kütleleri; kıta ve okyanus kütlelerinin çarpıştığı dalma-batma (subduction) kuşaklarında okyanus çökeli olan kireçtaşı blokları ile birlikte de bulunur. Buralara aynı zamanda melanj-sütur (ezik) kuşağı da denir. Serpantinperidotit ile kireçtaşı bloklarının yer aldığı böyle kuşaklar; Kuzey Anadolu dağ kuşağında Kırıkkale, Küre, Borçka ve Zigana dolaylarında, Oltu havzasının Gaziler çayı havzasında, Erzincan kuzey ve kuzeybatısında (Kızıldağ ve Esence dağları), Bat1 Toroslarda Antalya-Fethiye arasında ve Datça Yarımadasında, Güneydoğu Torosların güney eteklerinde Malatya-Hakkâri arasında yaygın olarak görülür. Böyle yerlerde yer yer kireçtaşı üzerinde kırmızı Akdeniz toprağı, serpantin üzerinde ise ayrışma derecesine göre farklı renkte topraklar görülür (Atalay 2017).

Serpantin içeren topraklar, ultramafik kayaların ayrışması ile oluşmaktadır. Bu magmatik veya metamorfik kayaların en az \%70'i ferromagnezyen veya mafik (magnezyum+ferrik-mafik) minerallerden oluşmaktadır (Kruckeberg 2002). Serpantin anakayadan gelişen topraklar zor ayrıştıkları için sığ ve taşlı topraklar oluşturmaktadır. Serpantinli topraklar önemli miktarda $\mathrm{Mg}$ içerir ve bu durum aslında bitkilerin yetişmesi, gelişmesi açısından uygun değildir. $\mathrm{Ni}, \mathrm{Co}, \mathrm{Cr}$ gibi ağır metaller bakımından zengin olan serpantinli topraklar yüksek oranda $\mathrm{Mg}$ ve $\mathrm{Fe}$ içerirken, $\mathrm{Ca}, \mathrm{K}, \mathrm{P}$ gibi bazı ana besinler açısından fakirdir (Avc1 2005).
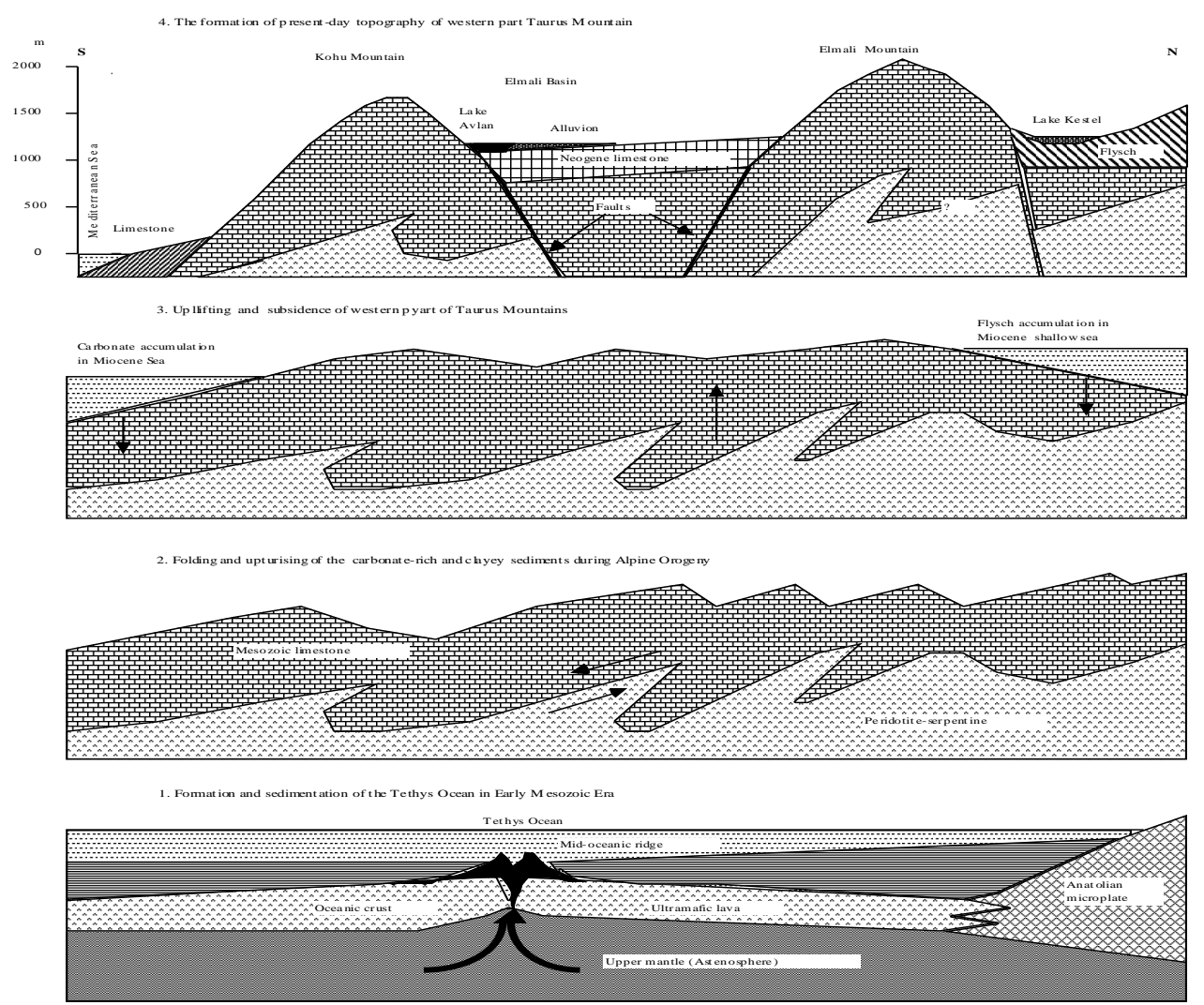

Şekil 1. Batı Toros dağlarının jeomorfolojik evrimi (Atalay ve ark. 2018).

Figure 1. The geomorphological evolution of the western Taurus Mountains. 


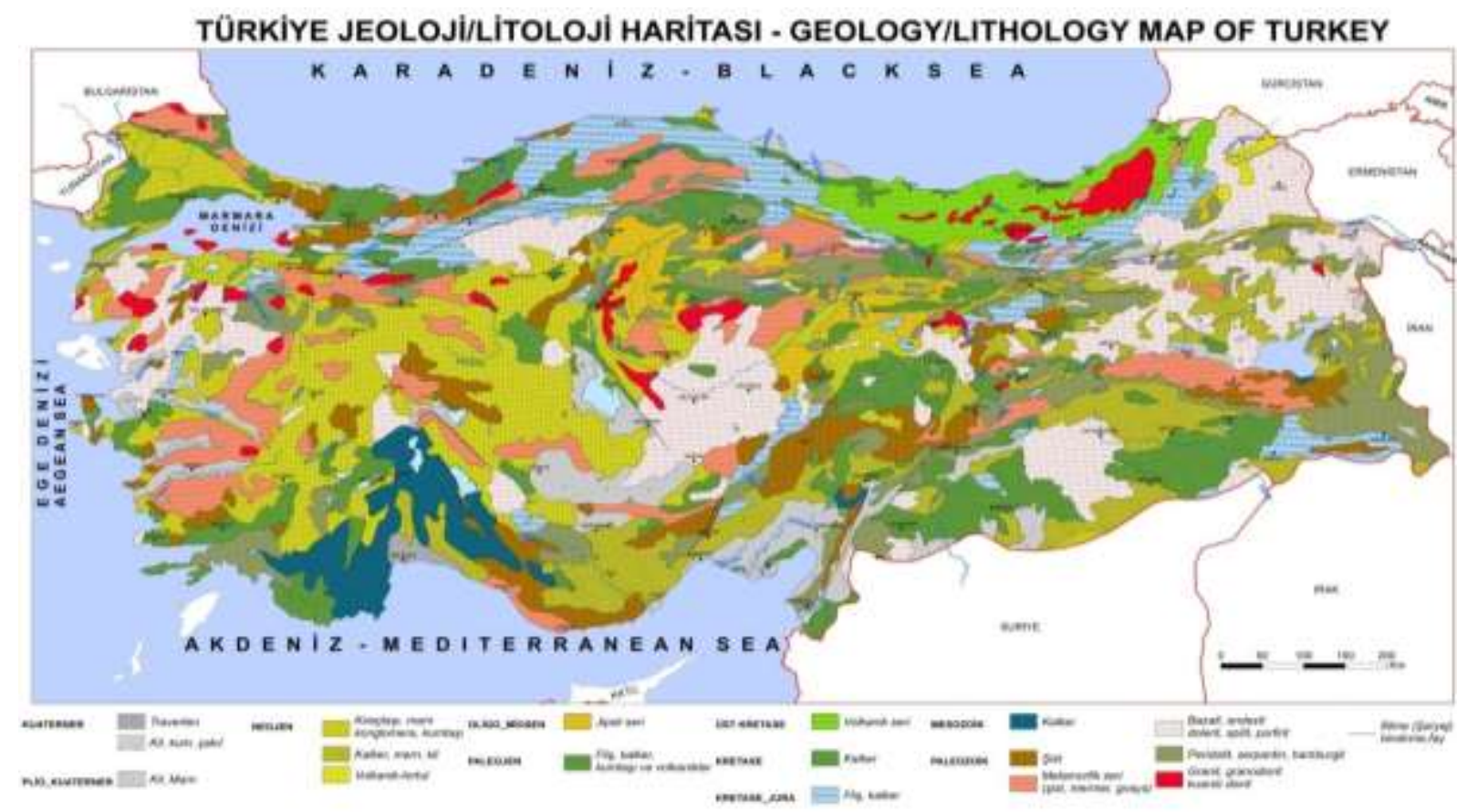

Şekil 2. Türkiye'nin jeoloji ve litoloji haritası (Atalay 2014).

Figure 2. Geology/Lithology map of Turkey.

Biyolojik olarak, serpantinli alanlar genellikle çevredeki diğer bölgelerle kıyaslandığında biyo çeşitlilik yönünden çok zengin floralara sahiptir. Çeşitliliğe rağmen seyrek bitki örtüsü erozyona ve toprak sıcaklığının yükselmesine sebep olmaktadır (Kruckeberg 2002). Bu faktörlerin her biri bitkiler için ek bir stres kaynağı teşkil etmektedir. Tüm bu kimyasal, fiziksel ve biyotik bileşenlerin oluşturduğu durum "serpantin sendromu" olarak isimlendirilmiştir (Jenny 1980). Serpantinli topraklarda yaşayan bitkiler tüm bu stres faktörlerinin tamamına karş1, adaptasyon geliştirmek zorundadırlar. Serpantinli topraklar birçok yerde bulunmakta, ancak düzensiz yamalı bir dağılım göstermektedir. Alanlar arasında bazı varyasyonlar olmasına rağmen, 3 ortak özellik ortaya konulmuştur: a) Düşük bitki verimliliği b) Yüksek endemizm oranı c) Komşu alanlardan farklılaşmış vejetasyon tipleri. Bu özelliklere bakarak serpantin problemi; Edafik Faktör, Bitki türleri-tepki ilişkisi (otoekoloji), Bitki toplulukları-tepki ilişkisi (sinekoloji) şeklinde 3 kısma ayrılmıştır (Whittaker 1954).

Serpantin probleminin edafik faktör kısmı, kimyasal, fiziksel ve biyotik bileşenleri ile çok yönlüdür. Bitkiler üzerindeki en etkili bileşenin kimyasal bileşendir (Kruckeberg 1985). Serpantinli topraklar düşük Ca:Mg oranı ile karakterize edilmektedir. $\mathrm{Bu}$ alanlarda $\mathrm{Ca}$ konsantrasyonu, civardaki diğer alanlara kıyasla çok düşüktür. Serpantinli topraklar aynı zamanda $\mathrm{Fe}, \mathrm{Ni}, \mathrm{Cr}$, Co gibi birçok bitkiye toksik etki yaratan ve kimi zaman bitki büyümesini sınırlandıran ağır metalleri yüksek miktarda içermektedir. Ayıca serpantinli topraklar bitkiler için elzem olan N, P, K gibi temel bitki besin maddeleri açısından fakirdir. $\mathrm{Bu}$ durum bitkiler açısından olumsuzluk yaratmaktadır (Gordon ve Lipman 1926; Vlamis ve Jenny 1948; Walker 1954; Proctor ve Woodell 1975; Brooks 1987).

Serpantinli topraklarda düşük konsantrasyonda bulunan Ca, serpantin sendromunun başlıca sebebidir. Yüksek $\mathrm{Mg}$ oranı da bu problemi daha da karmaşıklaştırmıştır. Bu hipotez birçok çalışma ile de desteklenmiştir (Walker 1948; Vlamis 1949;
Kruckeberg 1954; Walker ve ark. 1955). Serpantinin fiziksel koşulları da birçok bitki için oldukça zordur. Serpantin mostralar, genellikle sarp ve kayalık nispeten sı̆̆ topraklarda yayılırlar ve erozyona özellikle hassastırlar. Bu topraklardaki silt ve kil içeriği genelikle çok azdır (Walker 1954; Proctor ve Woodell 1975; Wallace 1983; Kruckeberg 2002). Bu nedenle serpantinli toprakların kimyasal yapısına olduğu kadar kuraklığa da tolerans kabiliyeti, bitkiler için hayati önem taşımaktadır.

Atalay $(2014,2017)$ ise serpantinleri ekolojik açıdan 2 gruba ayrilır. Bunlar;

a. İyi ayrışmış serpantinler: Killi ve killi balçık bünyede kırmızımsı renkli toprak vermekte olup her türlü bitkinin yetişmesini sağlar. Nitekim serpantinlerin iyi ayrıştığı düz ya da düze yakın kesimlerde boniteti (verimliliği) iyi, yani verimli ormanlar yer alır. Buna örnek olarak Eskele, Pos (Karsant1), Eskele, Yenice, Yılanlı (Muğla), Dirgine (Devrek, Yazıcık) orman işletme müdürlükleri sahasındaki gür karaçam ormanları verilebilir.

Eğimin az olduğu iyi ayrışmış serpantinler, katyon değişme kapasitesi yüksek olduğundan tarım yapılmaya uygun arazileri oluşturur. Örneğin Malatya-Karakaya baraj gölü arasında düzlük alanlarda kayısı bahçeleri serpantinler üzerinde yer alır. Burdur Gölhisar havzasının orta kesimindeki düzlük alanlarda serpantinler üzerinde gelişmiş topraklarda tarım yapılmaktadır. Burada serpantinler üzerindeki toprakların KDK 40-48 me $100 \mathrm{~g}^{-1}$, burada düzlük alanda 39 olan KDK, $2 \mathrm{~m}$ yakınındaki ayrışmanın az olduğu etekte $25 \mathrm{me} 100 \mathrm{~g} \mathrm{~g}^{-1}$ a düşer.

b. Az ayrışmış ve ayrışmakta olan serpantinler: Ormanların tahrip edildiği yerlerde toprakların aşınmasıyla yüzeye çıkmış, yer yer kayalıklar halinde görülen, ayrışmaya başladığ 1 yerlerde kil ve kirecin açığa çıkmasıyla beyazımsı renk almış serpantinleri kapsar. Akdeniz iklim bölgesindeki böyle serpantinler kızıl renkte, serpantin kütlesinin tamamen yüzeye çıktığı ve hiç ayrışmayan yerlerde yeşilimsi renktedir. Böyle 
serpantinlere örnek olarak Antalya-Kumluca arası, Köyceğiz dolayları, Datça Yarımadası, Nur dağlarının kuzey kesimi, Gölbaşı (Adıyaman) dolayları, Güneydoğu Toros dağlarının güney etekleri, Kırıkkale (Ankara) dolayları verilebilir.

Ayrışmamış ya da az ayrışmış sert serpantin kütleleri üzerinde verimi düşük ormanlar ile seyrek otsu bitkiler yer alır. Örneğin Antalya-Kemer, Kumluca'nın batısı, Datça Yarımadası'ndaki serpantinler üzerinde çalıya dönüşmüş kızılçamlar bulunur. Gölbaşı, Kırıkkale dolayları, Esence dağları (Erzincan), Narman Karadağ civarı ve Güneydoğu Torosların eteklerinde yer yer çıplak ve seyrek otsu bitkilerle kaplı durumdadır.

\section{Materyal ve Yöntem}

\subsection{Materyal}

Araştırma alanı, Akdeniz Bölgesinde Burdur ili sınırlarında yer alan, Burdur ve Gölhisar havzalarını kapsamaktadır. İklim, Akdeniz ve İç Anadolu iklimi arasındaki Akdeniz Geçiş İklim Bölgesi içerisinde yer alır. Etrafı dağlarla çevrili olmasından dolayı yağış gölgesinde kalan Burdur-Gölhisar Havzası'nda Akdeniz ve İç Anadolu iklimleri arasında hüküm süren yarıkurak iklim koşulları etkilidir. Bu iklim koşullarına bağlı olarak düzlük alanlarda altında kireç biriminin olduğu topraklar bulunur. Engebeli alanlarda ise ana materyalin etkisine bağl1 topraklar görülür. Topografyanın etkilediği yağış ve sıcaklık şartlarından dolayı 1200 m'ye kadar Akdeniz ikliminin klimaks ormanı olan kızılçam ormanları, bunun üzerinde Akdeniz dağ kuşağının ormanı içerisinde yer alan karaçam ormanları yer alır. Peridotit-serpantinler, Burdur-Gölhisar havzasının temelinde, Gölhisar çevresinde ve Burdur havzasının güneybatısında yaygın olarak görülmektedir. Atalay ve ark. (2019), bölgedeki serpantinleri ultramafik kayaçlar (peridodit-serpantinler) ve Serpantin-kireçtaşı karmaşığı (melanj) yapılar olmak üzere ikiye ayırırlar. Yer hareketleri sonucu volkanik kökenli peridotit-serpantin ile tortul kökenli kireçtaşlarının birbirlerine karışması sonucu oluşan melanj (Fransızca melange) karmaşık bir kütledir. Bu karmaşıklar, Yeşilova kasasının 2 km kadar doğusundaki yol yarması, Burdur Gölü'nün güneydoğusunda Çendik plajı ile Hacılar arasında tüm açıklığı ile görülür; ayrıca melanjlar, Burdur Gölü'nün güneybatısında Söğüt dağlarının güney ve güneybatı kesiminde de yaygındır (Şekil 3).

\subsection{Metod}

Araştırma alanındaki çalışmalar ofis, arazi ve laboratuvar şeklinde üç aşamada yürütülmüştür. Birinci aşamada daha önce bölgede yapılan çalışmalar, raporlar ve alana ait tüm veriler bir araya getirilerek, ilgili kurum ve kuruluşlarla işbirliği yapılmıştır. Araştıranın ikinci aşamasında, birinci aşamada toplanan bulgular 1şığında arazi çalışmaları gerçekleştirilmiştir. Arazide durum tespiti ve serpantin materyallerinden ve üzerinde oluşan topraklardan örnekleme yapılmıştır. Son aşamada ise ikinci aşamada alınan örneklerden Akdeniz Üniversitesi Ziraat Fakültesi Toprak Bilimi ve Bitki Besleme Bölümü laboratuvarında toprak tekstürü, organik madde, toprak reaksiyonu $(\mathrm{pH})$, kireç ve katyon değişim kapasitesi analizleri yapılmıştır.

Ana materyal ve toprakların tekstürü; Bouyoucos (1955) tarafindan belirlenen esaslara göre hidrometre yöntemiyle yapılmıştır. Analiz sonuçlarına göre bünye sınıfının belirlenmesinde 'Toprak Bünyesi Sınıflandırma Üçgeninden' yararlanılmıştır (Black 1957). Organik madde; Modifiye Walkley-Black metoduna göre tayin edilerek (Black 1965) ve Thun ve ark. (1955) tarafindan bildirilen esaslara göre sınıflandırılmıştır. Toprak reaksiyonu (pH); Jackson (1967)'a göre 1:2.5 toprak-su karışımında $\mathrm{pH}$ metre aleti kullanılarak ölçülmüş ve Kellog (1952)'a göre sınıflandırılmıştır. Kireç $\left(\mathrm{CaCO}_{3}\right)$; Toprak örneklerinin kireç içerikleri Scheibler Kalsimetresi ile ölçülmüş (Çağlar 1949) ve Aereboe ve Falke'ye göre sınıflandırılmıştır (Evliya 1964). Katyon değişim kapasitesi (KDK); $1 \mathrm{~N}$ amonyum asetat yöntemine göre belirlenmiştir (Kacar 1995).

\section{Bulgular ve Tartışma}

Serpantinler eğimli bölgelerde, koyu yeşil renkleri ile ayırt edilen ve demir magnezyum silikat bileşiminde iken, serpantinler ile kireçtaşlarının tektonik hareketlerle birbirlerine karıştığı melanj sahalarında ise farklı düzeyde ayrışmaya uğramış ve sarımsı, kahverengimsi, yeşilimsi renk tonlarında bir dizilim göstermişlerdir. Bu durumun tipik örneklerinden birisi Yeşilova kasabasının $2 \mathrm{~km}$ kadar batısında yer almaktadır (Çizelge 1).

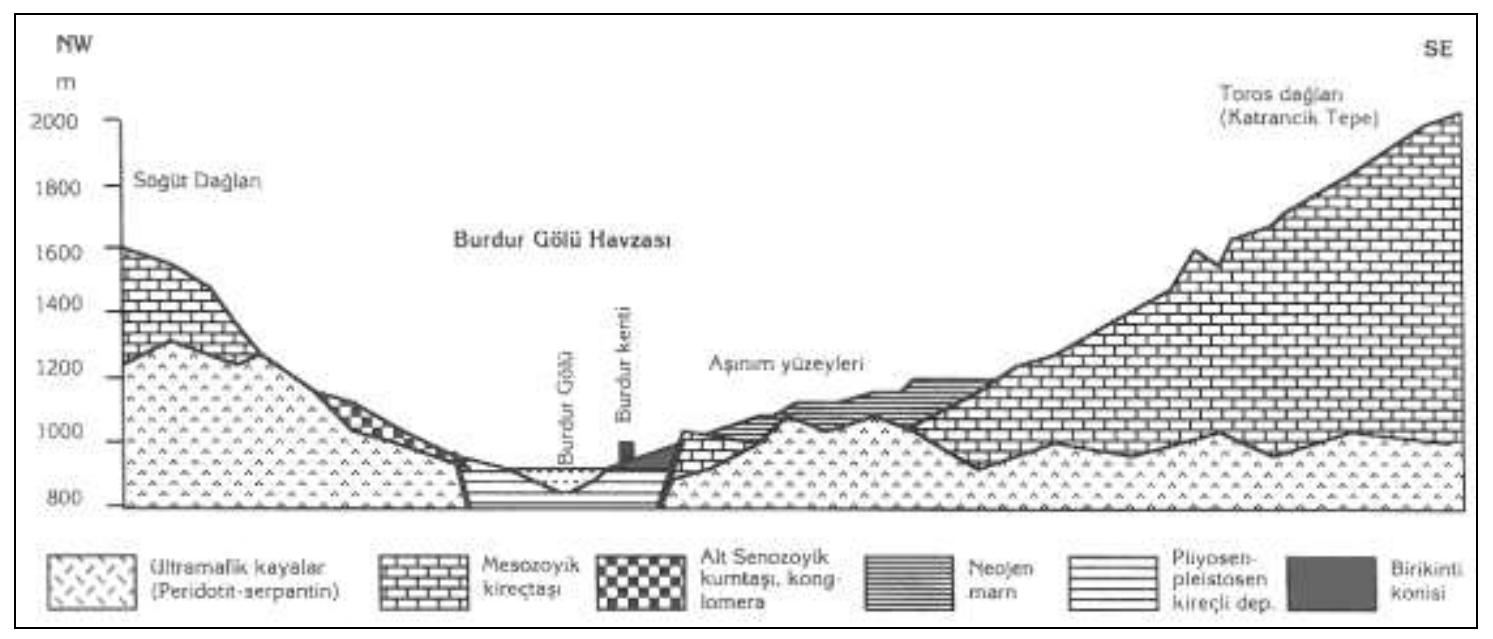

Şekil 3. Burdur havzasının jeoloji kesiti ve topografya profili (Atalay ve ark. 2019).

Figure 2. Geologic cross-section and topographic profile of Burdur basin. 
Yeşilova kasabasının $2 \mathrm{~km}$ kadar doğusundaki yol yarması boyunca alınan melanj sahasındaki 18 örnekte kirecin \%8 ile $\% 33$, katyon değişim kapasitesinin ise 13-43 me $100 \mathrm{~g}^{-1}$ arasında seyrettiği ölçülmüştür. Tekstür yönünden tın, tınlı kum ve kumlu tın gibi orta ve orta kaba tekstür bulunmuştur. Ayrışma derecesinin artmasina bağlı olarak tüm değerlerin genel olarak arttı̆̆ı görülmüştür (Çizelge 2).

Serpantinlerin farklı ayrışma derecelerine göre açığa çıkan bitki besin elementleri, bu kayaçların üzerinde oluşan toprakların ve ana materyalin verimliliğini doğrudan etkilemektedir. Genel bir değerlendirme yapıldığında yeni ayrışmakta olan özellikle Burdur Çentik plajı yakınındaki yol yarması ve Akgöl'ün güneyinde Taşpınar köyü güneyinde olduğu gibi eğimli yamaçlarda kil miktarının \%2'ye, kalsiyum karbonat miktarının da \%6'ya kadar düştügü yerlerde KDK'nin de 3.16 me $100 \mathrm{~g}^{-1}$ kadar inmektedir. Buralar genel olarak ot örtüsünden bile mahrumdur. Buna karşın Burdur güneydoğusunda neojen marnı altında yüzeye çıkmış en üstteki aşınım düzlüğü üzerinde ayrışmış serpantinin siltli tın bünyede ve KDK'nın 66 ve 44 me $100 \mathrm{~g}^{-1}$ olduğu tespit edilmiştir (Çizelge 3).
Pratikte iyi ayrışmış olan serpantinler üzerinde ağaç ve ağaççıkların, köklerinin kolayca derinlere doğru ilerlediği ve bitki beslenmesi için nispeten yeterli mineral maddelerin olduğu ve katyon değişim kapasitesinin artmasına bağlı olarak yoğun ve boniteti yüksek ağaç ve ağaççıklar yer aldığı gözlenmiştir. Buna karşın ayrışmanın çok zayıf olduğu serpantinler üzerinde ot örtüsünün çok zayıf olduğu ve ağaççık ve ağaçların adeta çalılaşmış halde olduğu görülmektedir. Diğer bir husus ise taşlı toprakların yer aldığı eğimli serpantin sahalarında ağaç köklerinin derinlere doğru ilerlediği ayrışmış kuşaklarda yöresel ölçüde iyi bonitette karaçam ve kızılçamlara rastlanılmaktadır.

Serpantinlerin derin olarak ayrıştığı düzlük yerlerde genellikle besin maddelerince nispeten zengin ve kil-killi tın bünyeli topraklarda, tarımsal bitkiler ve doğal bitki örtüsü yetişebilmektedir. Buna karşın eğimli sahalarda toprakların aşınmasıyla serpantinlerin yüzeye çıktığı kesimler, tarım uygun olmayan, verimiş düşük, IV ve $\mathrm{V}$ bonitette ormanların görüldüğü sahalar halindedir. Buralardaki sert kütle halinde olan, ayrışmamış serpantinler, köklerin derine doğru gelişmesini engelleyerek ağaçların çalı-ağaççık şeklinde olmasına yol açmaktadır.

Çizelge1. Yeşilova kasabasının $2 \mathrm{~km}$ batısındaki melanj sahasında serpantinlerin bazı fiziksel ve kimyasal analizleri.

Table 1. Some physical and chemical analysis in the field the melange $2 \mathrm{~km}$ west of the Yeşilova town.

\begin{tabular}{|c|c|c|c|c|c|c|c|c|c|c|}
\hline Ana materyal özellikleri & $\underset{(\%)}{\text { Kum }}$ & $\begin{array}{l}\text { Kil } \\
(\%)\end{array}$ & $\begin{array}{l}\text { Silt } \\
(\%)\end{array}$ & Tekstür & $\begin{array}{c}\mathrm{CaCO}_{3} \\
(\%)\end{array}$ & $\begin{array}{c}\mathrm{K} \\
\text { me } 100 \mathrm{~g}^{-1-}\end{array}$ & $\begin{array}{c}\text { Ca } \\
\text { me } 100 \mathrm{~g}^{-1}\end{array}$ & $\begin{array}{c}\mathrm{Mg} \\
\text { me } 100 \mathrm{~g}^{-1}\end{array}$ & $\begin{array}{l}\mathrm{Na} \\
\text { me } 100 \mathrm{~g}^{-1}\end{array}$ & $\begin{array}{c}\text { KDK } \\
\text { me } 100 \mathrm{~g}^{-1}\end{array}$ \\
\hline Çok ayrışmış serpantin & 46 & 25 & 29 & $\mathrm{~L}$ & 33 & 0.3 & 36.3 & 13.5 & 0.12 & 34.4 \\
\hline Çok ayrışmış kırmızımsı serpantin & 37 & 29 & 24 & $\mathrm{CL}$ & 23 & 0.4 & 37.5 & 14.7 & 0.13 & 43.8 \\
\hline Daha az ayrışmış serpantin & 79 & 9 & 12 & LS & 33.7 & 0.05 & 20.8 & 2.8 & 0.03 & 13.8 \\
\hline
\end{tabular}

Çizelge2. Yeşilova kasabasının $2 \mathrm{~km}$ doğusunda melanjlı sahasındaki serpantinlerin bazı fiziksel ve kimyasal analizleri.

Table 2. Some physical and chemical analysis in the field the melange $2 \mathrm{~km}$ east of the Yeşilova town.

\begin{tabular}{|c|c|c|c|c|c|c|c|}
\hline Serpantinin özelliği & $\operatorname{Kum}(\%)$ & Kil (\%) & Silt (\%) & Textür & pH (\%) & $\mathrm{CaCO}_{3}(\%)$ & KDK (me $100 \mathrm{~g}^{-1}$ ) \\
\hline Çok ayrışmış, kırmızımsı & 46 & 25 & 29 & Tin/L & 7.38 & 33 & 34.5 \\
\hline Az ayrışmış yeşil serp. & 80 & 9 & 12 & Tinlı kum/LS & 7.46 & 31.5 & 30.1 \\
\hline Orta derecede ayrışmış, iyi okside olmuş & 64 & 17 & 19 & Kumlu tın/SL & 7.54 & 33.2 & 29.3 \\
\hline Kırmızı ayrışmış, parmak erozyonlu & 37 & 29 & 34 & Killi tın/CL & 7.51 & 23 & 43.9 \\
\hline Ayrışmakta olan yeşilimsi & 79 & 9 & 12 & Tinlı kum/LS & 7.6 & 33.7 & 13.8 \\
\hline Serpantin üstü kestane renkli toprak & 36 & 34 & 30 & Killi tın CL & 7.43 & 7.9 & 36.4 \\
\hline
\end{tabular}

Çizelge3. Farklı derecede ayrışmış serpantinlerin fiziksel ve kimyasal özellikleri.

Table 3. Physical and chemical properties of serpentines decomposed at different levels.

\begin{tabular}{|c|c|c|c|c|c|c|c|c|c|}
\hline Toprak örnek yeri & Serpantinin ayrışma durumu & $\underset{(\%)}{\text { Kum }}$ & $\begin{array}{l}\text { Kil } \\
(\%)\end{array}$ & $\begin{array}{l}\text { Silt } \\
(\%)\end{array}$ & Tekstür & pH & $\begin{array}{c}\mathrm{CaCO}_{3} \\
(\%)\end{array}$ & $\begin{array}{c}\text { O.M. } \\
(\%)\end{array}$ & $\begin{array}{c}\text { KDK } \\
\left(\text { me } 100 \mathrm{~g}^{-1}\right)\end{array}$ \\
\hline Burdur çıkışı Çendik plajı & Yamaç üstü & 91 & 2 & 7 & Kum & 9.5 & 6.5 & 0.3 & 3.16 \\
\hline Burdur çıkışı Çendik plajı & Alt toprak & 77 & 8 & 15 & Kumlu tın SL & 9.73 & 11.5 & 0.3 & 2.19 \\
\hline Akçakale yolu & Serpantin toprağ / Serpentine soil & 61 & 20 & 19 & Kumlu tın SL & 9.13 & 1.7 & 0.7 & 23 \\
\hline Kayacık köyü & Serpantin unu & 65 & 10 & 25 & Kumlu tın SL & 9.12 & 7.11 & 0.5 & 21 \\
\hline Gölhisar girişi & Yeşil serpantin kumu & 73 & 7 & 20 & Kumlu tın SL & 8.94 & 1.52 & 0.4 & 20 \\
\hline Gölhisar girişi & Ayrışmış serpantin & 59 & 21 & 20 & Kumlu killi tın SCL & 7.41 & 3.7 & 0.5 & 24.3 \\
\hline Göl girişi & Ayrışmış serpantin & 79 & 7 & 14 & Kumlu tın SL & 7.62 & 5.11 & 0.5 & 33 \\
\hline Göl giriş & Az ayrışmış serpantin & 71 & 13 & 16 & Kumlu tın SL & 7.43 & 6.7 & 0.4 & 2 \\
\hline Akgöl-Yeşilova arası & Ayrışmış, parmak erozyonu & 67 & 6 & 27 & Siltli tın SiL & 8.55 & 14.9 & 0.1 & 1.8 \\
\hline Akgöl-Yeşilova arası & Bitkisiz ayrışmış serpantin & 67 & 6 & 27 & Siltli tın SiL & 7.87 & 3 & 0.4 & 2.0 \\
\hline Akgöl-Yeşilova arası & Bitkisiz ayrışmış serpantin & 71 & 13 & 16 & Siltli tın SiL & 7.49 & 1.6 & 0.2 & 12.9 \\
\hline Akgöl-Yeşilova arası & Ot örtülü & 65 & 9 & 26 & Siltli tın SiL & 7.28 & 2 & 2 & 14.5 \\
\hline 4. nolu taraça & Ayrışmış serpantin & 73 & 9 & 18 & Siltli tın SiL & 7.67 & 9.3 & 0.8 & 66 \\
\hline 4. nolu taraça & İyi ayrışmış serpantin & 65 & 7 & 28 & Siltli tın SiL & 7.67 & 17 & 0.5 & 44 \\
\hline
\end{tabular}


Gölhisar'ın batısındaki Akdağ'ın doğu eteklerinde olduğu gibi, serpantinler üzerindeki karaçamların boylu olanlarının serpantinlerin çatlakları boyunca kök geliştirdiği tespit edilmiştir. Eğimli sahalarda toprakların aşınarak serpantinlerin yüzeye çıktığı yerlerdeki litosollar üzerinde de sürekli otlatma nedeniyle karaçam gençlikleri pek görülmemektedir. Akdağ'da 1600-1800 m arasında doğal gençliğin getirilmesi için sahanın muhakkak suretle keçi otlatılmasına kapatılarak korunmaya alınması ve tohum yatağı oluşturmak üzere tırmıkla ince şeritler açılması gerekmektedir.

\section{Sonuç}

Deniz tabanına yayılan ultramafik bir kaya olan peridotitin bünyesine su almasiyla oluşan parlak yeşil görünümdeki serpantinler zor ayrışan kayalar arasındadır. Derin olarak ayrıştığı düzlük yerlerde genellikle besin maddelerince zengin toprak vermesi nedeniyle gerek tarım gerekse ormancılık açısından verimli sahaları oluşturur. Ancak serpantinlerin üzerinde killi ve killi tın bünyede toprakların oluştuğu düzlük alanlardaki tarım alanlarında sürüm işlemleri zorlaşır. Eğimli sahalarda toprakların aşınmasıyla serpantinlerin yüzeye çıktığ kesimler, tarıma uygun olmayan verimi düşük olan IV ve V bonitette ormanların görüldüğü sahalar halindedir. Buralardaki sert bir kütle halinde olan ayrışmamış serpantinler, köklerin derine doğru gelişmesini engellediğinden ağaçların çalı-ağaççık şeklide olmasına yol açmaktadır. Buna karşın ayrışmış serpantinler üzerinde kızılçamların derine doğru kök geliştirerek boy ve çaplarının arttığı saptanmıştır. Yine düz alanlarda da hububat tarımının yaygın olarak yapıldığı gözlenmektedir. Serpantinler üzerindeki bitki beslenmesinin ifadesi olan katyon değişme kapasitesini serpantinlerin ayrışmasıyla açığa çıkan Ca ve $\mathrm{Mg}$ iyonları önemli ölçüde belirlemektedir. Ayrıca melanj sahalarında serpantinlerin ezilmesi ve çatlaklı yapı kazanması ayrışmanın ilerlemesini kolaylaştırdığından KDK artmaktadır.

\section{Teşekkür}

Yapılan bu çalışmada, çizdiği şekiller ve koyduğu katkılar nedeni ile Prof. Dr. İbrahim ATALAY'a, Arazi çalışmalarına katk1 sağlayan Orman Mühendisi Oktay DEMİRCI'ye, ve Dr. Gafur GÖZÜKARA'ya, ayrıca çalışmamızda araç ve ekipman desteğini esirgemeyen Tarım ve Orman Bakanlığı, Isparta Orman Bölge Müdürü Sayın Kenan AKDUMAN'a ve ekibine destekleri için teşekkür ederim.

\section{Kaynaklar}

Atalay İ (2014) Türkiyenin ekolojik bölgeleri (Ecoregions of Turkey). Meta Basım, İzmir.

Atalay İ (2016) Uygulamalı Jeomorfoloji. Meta Basım, İzmir.

Atalay İ (2017) Türkiye Jeomorfolojisi. Meta Basım, İzmir.

Atalay İ, Altunbaş S, Khan AA, Coşkun M (2018) International, Geography Symposium on the 30th Anniversary of TUCAUM. ISBN: 978-605-136-416-2. Ankara.

Atalay İ, Altunbaş S, Siler M, Dal N (2019) Burdur-Gölhisar Havzasının Ekolojisi, Ekosistemleri ve Habitatları ile Mermer Ocaklarının Rehabilitasyonu. Tarım ve Orman Bakanlığı Yayınları (Baskıda).

Avcı M (2005) Diversity and endemism in Turkey's vegetation. İstanbul Üniversitesi Edebiyat Fakültesi Coğrafya Bölümü Coğrafya Dergisi 13: 27-55.

Black CA (1957) Soil-plant relationships. John Wiley and Sons, Inc., Newyork.
Black CA (1965) Methods of soil analysis Part 2, Amer. Society of Agronomy Inc., Publisher Madisson, Wilconsin, U.S.A., 13721376.

Bouyoucos GJ (1955) A recalibration of the hydrometer method for making mechanical analysis of the soils. Agronomy Journal 4(9): 434.

Brooks RR (1987) Serpentine and its Vegetation: A Multidisciplinary Approach. Dioscorides Press, Portland, OR .

Çağlar KÖ (1949) Toprak bilgisi. Ankara Üniversitesi Ziraat Fak. Yayınları Sayı: 10.

Cohen, R, Erol O (1969) Aspects of the Paleogeography of south Central Anatolia: Geog Journal 135: 338-398.

Cunningham WP, Saigo BW (1999) Environmental Science. WCB McGraw-Hill.

Evliya H (1964) Kültür bitkilerinin beslenmesi. Ankara. Üniv. Ziraat Fak. Yayınları, Yayın no: 36, Ankara, s. 292-294.

Gordon A, Lipman CB, (1926) Why are serpentine and other magnesian soils infertile?. Soil Science 22: 291-302.

Hoşgören MY (2000) Jeomorfolojinin Ana Çizgileri I, Rebel yayıncılık, İstanbul.

Jackson MC (1967) Soil chemical analysis. Prentice Hall of India Private'Limited, New Delhi.

Jenny H (1980) The Soil Resource: Origin and Behavior. New York: Springer-Verlag. pp. 377.

Kacar B (1995) Bitki ve toprağın kimyasal analizler: III. Toprak Analizleri. A. Ü. Ziraat Fakültesi Geliştirme Vakfı Yayınları No: 3.

Kellog CE (1952) Our garden soils. The Macmillan Company, Newyork.Kruckeberg AR, 1954. The ecology of serpentine soils: A symposium. III. Plant species in relation to serpentine soils. Ecology 35: 267- 74.

Kruckeberg AR (1985) California Serpentines: Flora, Vegetation, Geology, Soils, and Management Problems. Berkeley: Univ. Calif. Press. pp. 180.

Kruckeberg AR (2002) The influences of lithology on plant life. In Geology and Plant Life: The Effects of Landforms and Rock Type on Plants, pp. 160-81. Seattle/London: Univ. Wash. Press. pp. 362.

Proctor J, Woodell SRJ (1975) The ecology of serpentine soils. Advances in Ecological Research 9: 255-366.

Rajakaruna N, Boyd RS, (2014) Serpentine Soils. In: Oxford Bibliographies in Ecology. Ed. David Gibson. New York: Oxford University Press.

Thun R, Hermann R, Knickman E (1955) Die untersuchung von boden neuman verlag, Radelbeul und Berlin, s. 48-48.

Vlamis J, Jenny H (1948) Calcium deficiency in serpentine soils as revealed by absorbent technique. Science 107: 549-51.

Vlamis J (1949) Growth of lettuce and barley as influenced by degree of calcium saturation of soil. Soil Science 67: 453-66.

Walker RB (1948) A study of serpentine soil infertility with special reference to edaphic endemism. Ph.D. Thesis. Univ. Of California, Berkeley.

Walker RB (1954) The ecology of serpentine soils: A symposium. II. Factors affecting plant growth on serpentine soils. Ecology 35: 25966.

Walker RB, Walker HM, Ashworth PR (1955) Calcium-magnesium nutrition with special reference to serpentine soils. Plant Physiology 30: 214-21.

Wallace DR (1983) The Klamath Knot: Explorations of Myth and Evolution. San Francisco: Sierra Club Books. pp. 149.

Whittaker RH (1954) The ecology of serpentine soils: A symposium. I. Introduction. Ecology 35: 258-59. 